\title{
Hubungan Konsep Diri dan Kecemasan Siswa Terhadap Prestasi Belajar IPA Kelas IV SD Negeri Sumurgede Cilamaya Kulon - Karawang
}

\author{
Yulistina Nur DS
}

Pendidikan Guru Sekolah Dasar, FKIP, Universitas Buana Perjuangan Karawang JI HS. Ronggo Waluyo, Puseurjaya, Telukjambe Timur, Karawang, West Java, Indonesia

Corresponding author's : yulistina.nur@ubpkarawang.ac.id

\section{The Relationship between Self Concept and Students' Anxiety towards Class IV Science Learning Achievement at SD Negeri Sumurgede Cilamaya Kulon - Karawang}

Article info:

Article History

Available online

30 September 2018

Keywords:

self-concept, student anxiety, and science learning achievement

\begin{abstract}
Abstrak
Penelitian ini bertujuan untuk mengetahui pengaruh variabel konsep diri dan kecemasan siswa terhadap prestasi belajar IPA. Metode penelitian yang digunakan adalah survei, dengan jumlah sampel 93 siswa, yang diambil dengan teknik random sampling dari SD Negeri Sumurgede Cilamaya Kulon Karawang. Pengumpulan data menggunakan angket yang telah divalidasi sebelumnya. Analisis data menggunakan regresi ganda, dengan terlebih dahulu dilakukan uji normalitas, uji linieritas, dan uji multikolinieritas. Analisis data yang dilakukan memberikan hasil: 1) konsep diri berpengaruh positif dan signifikan terhadap prestasi belajar matematika, 2) kecemasan berpengaruh negatif, tetapi tidak signifikan terhadap prestasi belajar matematika, dan 3) konsep diri dan kecemasan siswa secara bersama-sama berpengaruh positif dan signifikan terhadap prestasi belajar IPA.
\end{abstract}

\begin{abstract}
:
This study aims to determine the effect of self-concept variables and student anxiety on science learning achievement. The research method used was a survey, with a sample of 93 students, taken by random sampling technique from Sumurgede Cilamaya Kulon-Karawang State Elementary School. Data collection uses questionnaires that have been previously validated. Data analysis using multiple regression, with the first normality test, linearity test, and multicollinearity test. Data analysis carried out gave results: 1) selfconcept had a positive and significant effect on mathematics learning achievement, 2) anxiety had a negative effect, but not significant on mathematics learning achievement, and 3) students' self-concept and anxiety together had a positive and significant effect towards science learning achievement.
\end{abstract}




\section{PENDAHULUAN}

Proses pendidikan yang berlangsung pada suatu lembaga pendidikan mempunyai standar dalam menilai sejauh mana tujuan pendidikan telah tercapai. Pencapaian tujuan pendidikan atau keberhasilan proses belajar mengajar dapat dilihat dari prestasi belajar siswayang dapat diukur dari nilai-nilai evaluasi dalam proses belajar mengajar. Menurut Muhammad Zainal Abidin(2013), untuk melihat berhasil tidaknya pendidikan di Indonesia dapat dilihat dari berbagai hal, misalnya standar nilai kelulusan, persentase kelulusan,dan mata pelajaran yang menjadi standar kelulusan. Salah satu mata pelajaran yang menjadi standar kelulusan dalam setiap jenjang pendidikan adalah IPA. Oleh karena itu IPA bisa dikatakan sebagai pelajaran yang sangat penting dan sangat berperan dalam upaya peningkatan mutu pendidikan Indonesia. Namun, opini negatif tentang IPA terlanjurberkembang dan melekat pada masyarakat khususnya siswa. IPA dianggap sebagai pelajaran yang sulit, bahkan cenderung menjadi pelajaran yang menakutkan.

Anggapan bahwa pelajaran IPA adalah pelajaran yang sulit dapat menimbulkan sikap yang berbeda untuk masing-masing siswa. Sikap yang timbul bisa positif, seperti menjadi bersemangat dalam mempelajari dan mengikuti proses pembelajaran IPA, karena merasa tertantang untuk menyelesaikan masalah-masalah IPA. Namun, bisa juga timbul sikap yang negatif, seperti menjadi malas untuk mempelajari IPA dan merasa tertekan atau mengalami gejala-gejala kecemasan dalam proses pembelajaran IPA. Seperti halnya anggapan bahwa IPA adalah pelajaran yang sulit, adanya nilai tes atau evaluasi dalam proses belajar mengajar IPA yang menjadi tolak ukur prestasi belajar IPA juga seringkali menimbulkan kecemasan bagi siswa dalam proses pembelajaran IPA. Tingkat kecemasan yang dirasakan siswa berbeda antara siswa satu dengan yang lainnya. Dampak dari kecemasan untuk masing-masing siswa juga berbeda.

Konsep diri terbentuk karena adanya interaksi seseorang dengan orang-orang disekitarnya. Apa yang dipersepsi seseorang tentang dirinya, tidak terlepas dari struktur, peran dan status sosial yang disandang orang tersebut. Struktur, peran dan status sosial merupakan gejala yang dihasilkan dari adanya interaksi antara individu yang satu dengan individu yang lain, antara individu dengan kelompok, atau kelompok dengan kelompok.

Kecemasan akan timbul jika individu menghadapi situasi yang dianggapnya mengancam dan menekan (Pangaribuan, 2001). Misalnya saja, apabila seseorang ingin melaksanakan atau melakukan suatu kegiatan atau pekerjaan yang baru, maka tentu orang tersebut akan merasa cemas dalam menghadapi pekerjaannya tersebut, apakah orang itu dapat melaksanakan dan menyelesaikan pekerjaan tersebut dengan hasil yang baik atau bahkan sebaliknya. Dalam kondisi dimana rasa cemas menghinggapi pikiran seseorang, tentunya orang tersebut akan berpikiran atau berangggapan yang negatif terhadap dirinya sendiri. Seperti misalnya, "pasti saya tidak bisa menyelesaikan pekerjaan tersebut dengan baik"; "pasti saya berhenti mengerjakan pekerjaan tersebut di tengah jalan"; "pasti hasilnya tidak memuaskan"; "pasti saya dicemooh orang banyak"; dan sebagainya.

Brook dan Emmert (Jalaluddin Rakhmat, 2005:105), mengatakan bahwa seseorang dengan konsep diri positif akan terlihat optimis, penuh percaya diri dan cenderung bersikap positif terhadap sesuatu, juga terhadap kegagalan yang dialami. 
Sebaliknya seseorang dengan konsep diri negatif akan terlihat lebih pesimis, menganggap dirinya tidak berdaya,merasa tidak disenangi,dan tidak diperhatikan. Dengan demikian,siswa dengan konsep diri negatif akan cenderung bersikap pesimistik terhadap kemampuannya padapelajaran IPA dan mudah menyerah dalam menghadapi masalah-masalah IPA. Dengan demikian, konsep diri negatif dapat dimungkinkan berpengaruh buruk terhadap prestasi belajar IPA.

Menurut Agus M. Hardjana (2003:96), konsep diri adalah hasil dari bagaimana seseorang melihat, merasai, dan menginginkan dirinya. Pendapat lain juga disampaikan oleh Jalaluddin Rakhmat (2005: 99-100), konsep diri merupakan pandangan dan perasaan seseorang tentang dirinya yang mencakup aspek psikologis, fisik, dan sosial.

Hurlock (2001: 58) mengatakan bahwa konsep diri adalah gambaran yang dimiliki orang tentang dirinya. Sedangkan menurut Hendrianti Agustiani (2006: 138), konsep diri merupakan gambaran yang dimiliki seseorang tentang dirinya, yang dibentuk melalui pengalaman-pengalaman yang diperoleh dari interaksi dengan lingkungannya.

Konsep diri seseorang itu terdiri dari konsep diri yang positif dan konsep diri negatif. Menurut Brooks dan Emmert (Rakhmat, 2003:105-106), orang yang memiliki konsep diri positif ditandai dengan 5 hal, yakni: (1) Yakin akan kemampuannya mengatasi masalah, (2) Merasa setara dengan orang lain, (3) Menerima pujian tanpa rasa malu, (4) Menyadari bahwa setiap orang mempunyai berbagai perasaan yang tidak seluruhnya disetujui masyarakat, dan (5) Mampu memperbaiki dirinya. Sedangkan orang yang memiliki konsep diri yang negatif ditandai pula dengan 5 hal, yakni: (1) Peka pada kritik, (2) Responsif sekali terhadap pujian, (3) Sikap hiperkritis, (4) Merasa tidak disenangi orang lain, dan (5) Sikap pesimis.

Dari pendapat-pendapat di atas, dapat dikatakan bahwa konsep diri merupakan gambaran, penilaian, dan harapan seseorang tentang kualitas dirinya yang berupa kemampuan dan keterbatasan atau kelemahan baik dari segi fisik, psikologis maupun sosial.

Semua orang pasti pernah merasa cemas. Kecemasan adalah hal normal sebagai manusia, tetapi bagi beberapa orang kecemasan dapat keluar kendali sampai mengacaukan gaya hidup mereka. Ini biasanya terjadi saat si penderita menjadi sangat ketakutan terhadap gejala-gejala fisik yang ia rasakan/alami dan mulai menghindari tempat-tempat dan situasi-situasi yang mereka rasa akan memunculkan gejala-gejala itu. Kecemasan "abnormal" ini seringkali ada karena suatu alasan.

Menurut Kartini Kartono (2003: 129), kecemasan merupakan bentuk kegelisahankegelisahan dan ketakutan terhadap sesuatu yang tidak jelas benar, yang difus atau baur, dan mempunyai ciri yang mengazab pada seseorang. Menurut Halgin dan Whitbourne (2010: 198), kecemasan merupakan sikap yang berorientasi pada masa depan dan bersifat umum yang mengacu pada kondisi ketika individu merasakan kekhawatiran/kegelisahan, ketegangan, dan rasa tidak nyaman yang tidak terkendali mengenai kemungkinan akan terjadinya hal buruk.

Kecemasan akan timbul jika individu menghadapi situasi yang dianggapnya mengancam dan menekan (Pangaribuan, 2001). Misalnya saja, apabila seseorang ingin melaksanakan atau melakukan suatu kegiatan atau pekerjaan yang baru, maka tentu orang tersebut akan merasa cemas dalam menghadapi pekerjaannya tersebut, 
apakah orang itu dapat melaksanakan dan menyelesaikan pekerjaan tersebut dengan hasil yang baik atau bahkan sebaliknya.

Dari uraian di atas, kecemasan dapat diartikan sebagai keadaan emosional yang mempunyai respon-respon fisiologis maupun psikologis sebagai dampak dari perasaan tidak aman terhadap kemungkinan buruk yang dimungkinkan akan terjadi. Jadi, dalam penelitian ini kecemasan menghadapi pembelajaran IPA merupakan keadaan emosional siswa yang mempunyai respon-respon fisiologis maupun psikologis sebagai dampak dari perasaan tidak aman terhadap kemungkinan buruk yang dimungkinkan akan terjadi ketika proses pembelajaran IPA.

Kirkland (1971:189) membuat suatu kesimpulan mengenai hubungan antara tes, kecemasan, dan hasil belajar :

1. Tingkat kecemasan yang sedang biasanya mendorong belajar, sedang tingkat kecemasan yang tinggi mengganggu belajar;

2. Siswa-siswa dengan tingkat kecemasan yang rendah lebih merasa cemas dalam menghadapi tes daripada siswa-siswa yang pandai;

3. Bila siswa cukup mengenal jenis tes yang akan dihadapi, maka kecemasan akan berkurang;

4. Pada tes-tes yang mengukur daya ingat, siswa-siswa yang sangat cemas memberikan hasil yang lebih baik daripada siswa-siswa yang kurang cemas. Pada tes-tes yang membutuhkan cara berpikir yang fleksibel, siswa-siswa yang sangat cemas hasilnya lebih buruk;

5. Kecemasan terhadap tes bertambah bila hasil tes dipakai untuk menentukan tingkat-tingkat siswa.

Data yang dikumpulkan Spielberger (1966:188) menunjukkan bahwa siswa-siswa dengan tingkat kecemasan yang rendah berprestasi lebih baik daripada siswa-siswa dengan tingkat kecemasan yang tinggi.

Menurut Freud (Sumadi Suryabrata, 2008:139), kecemasan dibagi menjadi 3, yaitu:

1. Kecemasan Realistis,

Merupakan kecemasan terhadap bahaya atau ancaman dari dunia luar yang bisa dikatakan sebagai sumber dari kecemasan-kecemasanyang lain.

2. Kecemasan Neurotis,

Merupakan kecemasan yang berkaitan dengan insting-insting yang tidak dapat dikendalikan, sehingga menyebabkan orang berbuat sesuatu yang diancam dengan hukuman.

3. Kecemasan Moral (Perasaan Berdosa),

Merupakan kecemasan kata hati. Orang yang super egonya berkembang baik akan cenderung merasa berdosa apabila melakukan atau bahkan baru berfikir untuk melakukan sesuatu yang bertentangan dengan norma-norma moral yang berlaku.

\section{METODE PENELITIAN}

Penelitian ini merupakan penelitian korelasional yang bertujuan untuk mendeskripsikan hubungan antara konsep diri dan kecemasan siswa menghadapi pembelajaran IPA dengan prestasi belajar IPA pada siswa kelas IV SD Negeri Sumurgede-Cilamaya KulonKarawang tahun pelajaran 2017/2018. Penelitian ini juga 
merupakan penelitian ex-post facto, karena tidak melakukan perubahan terhadap responden. Untuk memberikan gambaran yang jelas, maka penelitian ini dapat digambarkan dalam desain penelitian berikut ini:

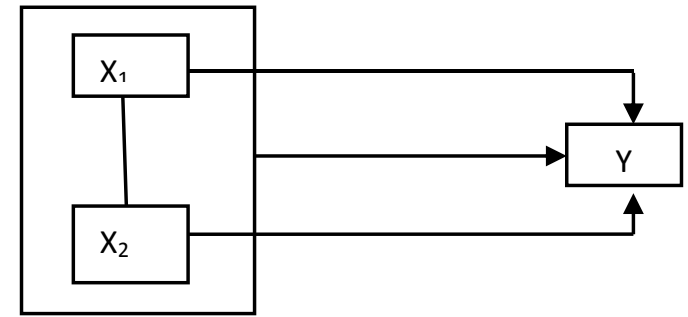

Gambar 1. Desain Penelitian

Penelitian ini bertujuan untuk mendeskripsikan hubungan antara konsep diri dengan prestasi belajar IPA, mendeskripsikan hubungan antara kecemasan menghadapi pembelajaran IPA dengan prestasi belajar IPA dan mendeskripsikan hubungan antara konsep diri dan kecemasan menghadapi pembelajaran IPA secara bersama-sama dengan prestasi belajar IPA.

Populasi dalam penelitian ini adalah seluruh siswa kelas IV SD Negeri Sumurgede Cilamaya Kulon Karawang tahun pelajaran 2017/2018 yang berjumlah 93 siswa. Dengan metode penarikan sampel Simple Random Sampling, diambil 93 siswa untuk sampel penelitian. Pengumpulan data konsep diri dan kecemasan menghadapi pembelajaran IPA dilakukan dengan metode angket, sedangkan data prestasi belajar IPA diperoleh dari soal tes IPA. Teknik analisis data yang digunakan dalam penelitian ini adalah analisis korelasi parsial, analisis regresi linier sederhana dan analisis regresi linier ganda dengan taraf signifikansi sebesar 5\%. Menurut Ruseffendi dan Achmad Sanusi (Tukiran Taniredja dan Hidayati Mustafidah, 2011 : 39), besar ukuran sampel minimum pada jenis penelitian korelasional adalah 30 subyek.

Instrumen yang digunakan dalam penelitian ini berupa angket konsep diri, angket kecemasan menghadapi pembelajaran IPA, dan tes prestasi belajar. Berdasarkan kajian teori, angket konsep diri tersusun dari tiga aspek, yaitu aspek fisik, aspek psikologis, dan aspek sosial yang kemudian masing-masing aspek akan dijabarkan ke dalam beberapa indikator. Kemudian, indikator-indikator tersebut dituangkan dalam bentuk butir-butir item. Angket konsep diri menggunakan skala Likert dengan 4 alternatif pilihan, yaitu Sangat Sesuai (SS), Sesuai (S), Kurang Sesuai (KS) dan Tidak Sesuai (TS). Butir angket dinyatakan dalam duabentuk, yaitu pernyataan yang bersifat positif dan pernyataan yang bersifat negatif. Pernyataan positif adalah pernyataan yang mendukung aspek konsep diri positif, sedangkan pernyataan negatif adalah pernyataan yang mendukung aspek konsep diri negatif dan ktentuan penskoran dan kisi-kisi angket konsep diri.

Angket kecemasan menghadapi pembelajaran IPA tersusun dari dua aspek, yaitu aspek psikologis dan aspek fisiologis yang kemudian masing-masing aspekakan dijabarkan ke dalam indikator-indikator. Kemudian, indikator-indikator tersebut dituangkan dalam bentuk butir-butir item. Angket kecemasan menghadapi pembelajaran IPA menggunakan skala Likert dengan 4 alternatif pilihan, yaitu Selalu $(\mathrm{SL})$, Sering (S), Jarang (J) dan Tidak Pernah (TP). Butir angket dinyatakan dalam dua bentuk, yaitu pernyataan yang bersifat positifdan pernyataan yang bersifat negatif. Pernyataan positif adalah pernyataan yang mendukung aspek kecemasan menghadapi pembelajaran IPA. sedangkan pernyataan negatif adalah pernyataan yang tidak 
mendukung aspek kecemasan menghadapi pembelajaran IPA. Adapun ketentuan penskoran dan kisi-kisiangket kecemasan dalam menghadapi pembelajaran IImu Pengetahuan Alam (IPA)

\section{HASIL DAN PEMBAHASAN}

Penelitian ini merupakan penelitian korelasional yang bertujuan untuk mendeskripsikan hubungan antara konsep diri dan kecemasan siswa menghadapi pembelajaran IPA dengan prestasi belajar IPA pada siswa kelas IV SD Negeri Sumurgede - Cilamaya Kulon Karawang tahun pelajaran 2017/2018.

Penelitian ini juga merupakan penelitian ex-post facto, karena tidak melakukan perubahan terhadap responden. Berdasarkan hasi perhitungan, didapatkan tabel frekuensi kumulatif untuk variabel prestasi belajar IPA sebagai berikut.

Gambar 1. Frekuensi Prestasi Belajar IPA

\begin{tabular}{|c|c|c|c|c|c|}
\hline & & Frequency & Percent & Valid Percent & $\begin{array}{c}\text { Cumulative } \\
\text { Percent }\end{array}$ \\
\hline \multirow[t]{23}{*}{ Valid } & 15,00 & 1 & 1,1 & 1,1 & 1,1 \\
\hline & 18,00 & 3 & 3,2 & 3,2 & 4,3 \\
\hline & 19,00 & 1 & 1,1 & 1,1 & 5,4 \\
\hline & 20,00 & 4 & 4,3 & 4,3 & 9,7 \\
\hline & 21,00 & 2 & 2,2 & 2,2 & 11,8 \\
\hline & 22,00 & 7 & 7,5 & 7,5 & 19,4 \\
\hline & 23,00 & 6 & 6,5 & 6,5 & 25,8 \\
\hline & 24,00 & 6 & 6,5 & 6,5 & 32,3 \\
\hline & 25,00 & 7 & 7,5 & 7,5 & 39,8 \\
\hline & 26,00 & 9 & 9,7 & 9,7 & 49,5 \\
\hline & 27,00 & 10 & 10,8 & 10,8 & 60,2 \\
\hline & 28,00 & 12 & 12,9 & 12,9 & 73,1 \\
\hline & 29,00 & 2 & 2,2 & 2,2 & 75,3 \\
\hline & 30,00 & 10 & 10,8 & 10,8 & 86,0 \\
\hline & 31,00 & 1 & 1,1 & 1,1 & 87,1 \\
\hline & 32,00 & 2 & 2,2 & 2,2 & 89,2 \\
\hline & 34,00 & 2 & 2,2 & 2,2 & 91,4 \\
\hline & 35,00 & 1 & 1,1 & 1,1 & 92,5 \\
\hline & 36,00 & 2 & 2,2 & 2,2 & 94,6 \\
\hline & 37,00 & 1 & 1,1 & 1,1 & 95,7 \\
\hline & 38,00 & 3 & 3,2 & 3,2 & 98,9 \\
\hline & 40,00 & 1 & 1,1 & 1,1 & 100,0 \\
\hline & Total & 93 & 100,0 & 100,0 & \\
\hline
\end{tabular}

Hasil Perhitungan Statistik Deskriptif Variabel Prestasi Belajar

Statistics

\begin{tabular}{|c|c|c|}
\hline \multicolumn{3}{|l|}{ Prestasi Belajar } \\
\hline $\mathrm{N}$ & Valid & 93 \\
\hline & Missing & 0 \\
\hline Mean & & 26,6667 \\
\hline Std. Error of Mean & &, 50739 \\
\hline Median & & 27,0000 \\
\hline Mode & & 28,00 \\
\hline Std. Deviation & & 4,89306 \\
\hline Variance & & 23,942 \\
\hline Skewness & &, 469 \\
\hline Std. Error of Skewness & &, 250 \\
\hline Kurtosis & & ,446 \\
\hline Std. Error of Kurtosis & &, 495 \\
\hline Range & & 25,00 \\
\hline Minimum & & 15,00 \\
\hline Maximum & & 40,00 \\
\hline Sum & & 2480,00 \\
\hline
\end{tabular}


Dari data hasil tes hasil belajar, terletak pada rentangan skor $15-40$, dengan nilai rata-rata sebesar 26,67; nilai modus sebesar 28; median sebesar 27 dan simpangan baku sebesar 4,89 . Dari analisis deskriptif di atas dapat disimpulkan bahwa prestasi belajar terletak pada kategori sedang, hal ini terlihat dari besar rata-rata dan modus yang berada sedikit di atas median.

Dengan menggunakan Analisis Kolmogorov Smirnov dalam SPSS 15.0. Distribusi data dikatakan normal jika nilai sig $>0,05$. Dari perhitungan menggunakan program SPSS 15.0 diperoleh hasil yang dinyatakan dalam tabel berikut:

\section{One-Sample Kolmogorov-Smirnov Test}

\begin{tabular}{|ll|r|}
\hline & & Hasil Belajar \\
\hline $\mathrm{N}$ & & 93 \\
Normal Parameters a,b & Mean & 26,6667 \\
& Std. Deviation & 4,89306 \\
Most Extreme & Absolute &, 124 \\
Differences & Positive &, 124 \\
& Negative &,- 052 \\
Kolmogorov-Smirnov Z & & 1,194 \\
Asymp. Sig. (2-tailed) & &, 116 \\
\hline
\end{tabular}

a. Test distribution is Normal.

b. Calculated from data.

Dari tabel perhitungan tersebut diperoleh nilai sig sebesar 0,116 ; sehingga dapat disimpulkan bahwa data untuk variabel prestasi belajar berdistribusi normal. Uji linieritas dimaksudkan untuk melihat bentuk persamaan regresi yang terbentuk dari tiap variabel bebas terhadap variabel terikat, dalam hal ini $\mathrm{X} 1$ terhadap $\mathrm{Y}$, dan $\mathrm{X} 2$ terhadap Y.

Hipotesis yang diuji adalah:

HO : persamaan regresi berbentuk linier

$\mathrm{H} 1$ : persamaan regresi tidak berbentuk linier

Dengan kriteria uji sebagai berikut:

Jika sig Deviation from Linearity $>0,05$; maka tolak $\mathrm{H} 1$ dan terima $\mathrm{H} 0$ Jika sig Deviation from Linearity $<0,05$; maka terima $\mathrm{H} 1$ dan tolak $\mathrm{H} 0$

Dari hasil perhitungan menggunakan program SPSS 15.0, diperoleh hasil yang dinyatakan dalam tabel berikut ini.

Tabel 1. Hasil perhitungan linieritas $X_{1}$ terhadap $Y$ (ANOVA Table)

\begin{tabular}{|c|c|c|c|c|c|c|c|}
\hline & & & $\begin{array}{l}\text { Sum of } \\
\text { Squares }\end{array}$ & df & $\begin{array}{l}\text { Mean } \\
\text { Square }\end{array}$ & $\mathbf{F}$ & Sig. \\
\hline \multirow{5}{*}{$\begin{array}{l}\text { Prestasi } \\
\text { Belajar } \\
\text { Konsep Diri }\end{array}$} & $\begin{array}{l}\text { Between } \\
\text { Groups }\end{array}$ & (Combined) & 1011,798 & 18 & 56,211 & 3,493 & ,000 \\
\hline & & Linearity & 356,195 & 1 & 356,195 & 22,134 & ,000 \\
\hline & & $\begin{array}{l}\text { Deviation from } \\
\text { Linearity }\end{array}$ & 655,603 & 17 & 38,565 & 2,396 & ,065 \\
\hline & \multicolumn{2}{|c|}{ Within Groups } & 1190,869 & 74 & 16,093 & & \\
\hline & \multicolumn{2}{|l|}{ Total } & 2202,667 & 92 & & & \\
\hline
\end{tabular}


Tabel 2. Hasil perhitungan linieritas $\mathrm{X}_{2}$ terhadap $\mathrm{Y}$ (ANOVA Table)

\begin{tabular}{|c|c|c|c|c|c|c|c|}
\hline & & & $\begin{array}{l}\text { Sum of } \\
\text { Squares }\end{array}$ & df & $\begin{array}{l}\text { Mean } \\
\text { Square }\end{array}$ & $\mathrm{F}$ & Sig. \\
\hline \multirow{5}{*}{$\begin{array}{l}\text { Prestasi Belajar } \\
\text { * Kecemasan }\end{array}$} & \multirow{3}{*}{$\begin{array}{l}\text { Between } \\
\text { Groups }\end{array}$} & (Combined) & 767,809 & 24 & 31,992 & 1,516 & ,093 \\
\hline & & Linearity & 79,477 & 1 & 79,477 & 3,767 & ,056 \\
\hline & & $\begin{array}{l}\text { Deviation from } \\
\text { Linearity }\end{array}$ & 688,332 & 23 & 29,927 & 1,418 & ,135 \\
\hline & \multicolumn{2}{|c|}{ Within Groups } & 1434,858 & 68 & 21,101 & & \\
\hline & \multicolumn{2}{|l|}{ Total } & 2202,667 & 92 & & & \\
\hline
\end{tabular}

Tabel 3. Rekap Hasil Perhitungan

Uji Linieritas

\begin{tabular}{cc}
\hline Persamaan regresi yang Diuji & Sig Deviation from Linearity \\
\hline X1 terhadap Y & 0,065 \\
X2 terhadap Y & 0,135 \\
\hline
\end{tabular}

Dari tabel di atas terlihat bahwa untuk setiap persamaan regresi yang diuji nilai sig Deviation from Linearity memiliki nilai sig > 0,05; atau dengan kata lain, seluruh persamaan regresi yang terbentuk merupakan persamaan garis lurus.

Tabel 4. Hasil Perhitungan Uji Multikolinieritas

Coefficients ${ }^{\mathrm{a}}$

\begin{tabular}{|c|c|c|c|}
\hline \multirow[b]{2}{*}{ Model } & & \multicolumn{2}{|c|}{ Collinearity Statistics } \\
\hline & & Tolerance & VIF \\
\hline \multirow[t]{3}{*}{1} & (Constant) & & \\
\hline & Konsep Diri & ,901 & 1,110 \\
\hline & Kecemasan & ,901 & 1,110 \\
\hline
\end{tabular}

a. Dependent Variable: Prestasi Belajar

Dari tabel di atas terlihat nilai VIF untuk variabel konsep diri adalah 1,110; dan untuk variabel kecemasan adalah 1,110. Dari tabel tersebut dapat dikatakan bahwa seluruh variabel memiliki nilai VIF < 10; atau dengan kata lain, tidak terjadi multikolinieritas, sehingga uji hipotesis menggunakan regresi ganda dapat dilanjutkan.

Hipotesis penelitian ini diuji menggunakan regresi linier ganda, yang dilakukan menggunakan bantuan program SPSS 15.0.

Tabel 5. Pengujian Hipotesis

Coefficients $^{a}$

\begin{tabular}{llrrrrrr}
\hline & & \multicolumn{2}{c}{$\begin{array}{c}\text { Unstandardized } \\
\text { Coefficients }\end{array}$} & \multicolumn{2}{c}{$\begin{array}{c}\text { Standardizer } \\
\text { Coefficients }\end{array}$} & & \\
\cline { 3 - 6 } Model & & \multicolumn{2}{c}{ B } & Std. Erro & Beta & & \multicolumn{1}{c}{ S } \\
\hline 1 & (Constant) &, 829 & 13,823 & &, 060 &, 952 \\
& Konsep Diri &, 308 &, 082 &, 380 & 3,747 &, 000 \\
& Kecemasan &,- 056 &, 082 &,- 070 &,- 691 &, 491 \\
\hline
\end{tabular}

a. Dependent Variable: Prestasi Belajar 
Dari pengolahan data (yang ditunjukkan dalam tabel), diperoleh hasil besar $\mathrm{t}$ hitung untuk variabel konsep diri sebesar 3,747 dan signifikansi korelasi sebesar = 0,000 . Dari hasil tersebut terlihat bahwa besar sig $<0,05$; sehingga dapat diputuskan tolak Ho dan terima $\mathrm{H} 1$, yang artinya Konsep diri memberikan pengaruh positif dan signifikan terhadap prestasi belajar. Hal ini diperlihatkan dari hasil perhitungan yang menunjukkan nilai t hitung $=3,747$ dan sig $=0,000$, lebih kecil dibandingkan 0,05.

Dari pengolahan data di atas, diperoleh hasil besar $\mathrm{t}$ hitung untuk variabel kecemasan siswa sebesar $-0,691$ dan signifikansi korelasi sebesar $=0,4910$. Dari hasil tersebut terlihat bahwa besar sig >0,05; kecemasan memberikan pengaruh negatif, tetapi tidak signifikan terhadap prestasi belajar. Hal ini diperlihatkan dari hasil perhitungan yang menunjukkan nilai thitung $=-0,691$ dan sig $=0,491$, lebih kecil dibandingkan 0,05.

Dari pengolahan data (seperti yang ditunjukkan dalam tabel), diperoleh hasil korelasi antara variable konsep diri dan kecemasan secara bersama-sama dengan prestasi belajar adalah 0,408; yang berarti Konsep diri dan kecemasan secara bersama-sama memberikan pengaruh positif dan signifikan terhadap prestasi belajar. Hal ini diperlihatkan dari koefisien korelasi antara konsep diri dan kecemasan secara bersama-sama dengan prestasi belajar sebesar 0,408 dan koefisien determinasi sebesar $16,6 \%$.

\section{KESIMPULAN}

Berdasarkan dari hasil pengujian hipotesis penelitian dan analisis pengolahan data, maka dapat disimpulkan sebagai berikut:

1. Konsep diri memberikan pengaruh positif dan signifikan terhadap prestasi belajar. $\mathrm{Hal}$ ini diperlihatkan dari hasil perhitungan yang menunjukkan nilai $\mathrm{t}$ hitung $=3,747$ dan sig $=0,000$, lebih kecil dibandingkan 0,05.

2. Kecemasan memberikan pengaruh negatif, tetapi tidak signifikan terhadap prestasi belajar. Hal ini diperlihatkan dari hasil perhitungan yang menunjukkan nilai thitung = 0,691 dan sig $=0,491$, lebih kecil dibandingkan 0,05.

3. Konsep diri dan kecemasan secara bersama-sama memberikan pengaruh positif dan signifikan terhadap prestasi belajar. Hal ini diperlihatkan dari koefisien korelasi antara konsep diri dan kecemasan secara bersama-sama dengan prestasi belajar sebesar 0,408 dan koefisien determinasi sebesar $16,6 \%$. Persamaan regresi yang terbentuk adalah $\hat{Y}=0,829+0,308 X 1-0,056 X 2$. Hal ini dapat diartikan bahwa semakin baik konsep diri dan semakin berkurang kecemasan, maka semakin baik pula prestasi belajarnya.

\section{DAFTAR PUSTAKA}

Anas Sudijono. (2006). Pengantar Evaluasi Pendidikan. Jakarta: PT. Rajagrafindo Persada.

Arikunto, Suharsimi. (2009). Dasar-dasar Evaluasi Pendidikan (Edisi Revisi). Jakarta: Bumi Aksara. 
Burns, R.B. (1993). Konsep Diri: Teori, Pengukuran, Perkembangan dan Perilaku. Jakarta: Arcan.

Gunawan Pamungkas. (2011). Konsep Kecemasan. http://teorikecemasan.blogspot.com/Tanggal akses: 25 Agustus 2013.

Hurlock, Elizabeth B. (2001). Perkembangan Anak, Jilid 2. Jakarta: Erlangga.

Hartono. (2012). Statistik untuk Penelitian. Yogyakarta: Pustaka Pelajar.

Jacinta F. Rini. (2002). Konsep Diri. http://www.e-psikologi.com/epsi/search.asp. Tanggal akses: 05 September 2013.

Mulyasa, E. (2009). Menjadi Guru Profesional- Menciptakan Pembelajaran Kreatif dan Menyenangkan.Bandung: Remaja Rosdakarya.

Pudjijogyanti, Clara R. (1988). Konsep Diri Dalam Pendidikan. Jakarta: Penerbit Arcan.

Purwanto, M. Ngalim.(1992).Psikologi Pendidikan.Bandung: Remaja Rosda Karya.

Sudjana, Nana. (2009). Penilaian Hasil Proses Belajar Mengajar. Bandung: Remaja Rosdakarya.

Sugiyono. (2007). Statistik Nonparametris. Bandung: Alfabeta.

Sutrisno Hadi. (2001). Metodoology Research. Yogyakarta: Penerbit Andi.

Syaiful Sagala. (2006). Konsep dan Makna Pembelajaran. Bandung: Alfabeta.

Tulus Winarsunu. (2002). Statistik dalam Penelitian Psikologi dan Pendidikan. Malang: UMM Press. 